\title{
OBSERVATIONS ON GROUP-F STREPTOCOCCI FROM HUMAN SOURCES
}

\author{
A. J. WORT \\ Division of Microbiology, The Izaak Walton Killam Hospital for Children*, and \\ the Department of Microbiology, Dalhousie University, Halifax, \\ Nova Scotia B3J 3G6, Canada
}

IN comparison with the vast literature concerning group-A streptococci, our knowledge of group-F streptococci is very meagre and there is little published work concerning them. This report documents a series of 22 strains isolated from children and puerperal women during about 4 years and discusses their significance in human disease.

\section{MATERIALS AND METHODS}

Primary cultures were inoculated on horse-blood agar (BBL Columbia Base; Becton, Dickinson and Co., Canada, Ltd, Mississauga, Ontario) and incubated at $37^{\circ} \mathrm{C}$ under aerobic and anaerobic conditions for up to $48 \mathrm{~h}$. Haemolytic colonies were examined microscopically and Gram-positive cocci were inoculated into Todd-Hewitt Broth (BBL). These cultures were incubated at $37^{\circ} \mathrm{C}$ overnight and used for preparing antigen by the method of Rantz and Randall (1955). Lancefield groups were determined by the microprecipitin technique (Lancefield, 1938) with grouping sera purchased from Burroughs Wellcome Ltd, Beckenham, Kent.

Sensitivity to bacitracin (Maxted, 1953) was tested with standard bacitracin disks (BBL Taxo A) and Columbia horse-blood agar. Some strains were inoculated on to aesculin-bileagar slopes (Difco Aesculin Bile Agar, Difco Laboratories, Detroit, USA) or aesculin-agar slopes.

\section{RESULTS}

During the period 1971-74 inclusive, some 3500 strains of haemolytic streptococci were subjected to Lancefield grouping. Of these, 22 strains isolated from 22 different patients belonged to Lancefield's group F. Eight of the strains were from peritoneal-cavity swabs taken at operation, in seven for acute appendicitis and in one for ruptured jejunum; five strains were from the vagina of puerperal women; two isolates were from urine, and one from the perineum of one of these patients was presumably related to the infection of the urine. One strain came from an abscess in the neck of a patient who had a history of dental infection, one from an ear swab from a child with cerebrospinal fluid (CSF) leaking from the ear, and one from a maxillary sinus.

All group-F organisms were isolated from mixed cultures and since they were selected for further study because they were haemolytic on horse-blood agar, non-haemolytic strains would not have been recognised. Eight strains were quite fastidious anaerobes, two were microaerophilic, and 12 grew readily and were easily recognised on aerobic culture.

Colonial morphology was variable. Nine of the strains grew very slowly, producing the classically described pinpoint colonies and attracting attention because of their haemolysis (Long and Bliss, 1934) but 13 strains produced colonies that were easily visible after overnight incubation. One strain was isolated repeatedly in pure culture from the urine and perineum of a patient who had undergone a renal transplant. Several strains, including this one, grew so slowly in Todd-Hewitt broth that incubation for 5-7 days was required before growth was adequate for the production of grouping antigen. All strains gave clear precipitin

Received 20 Jan. 1975; accepted 24 Feb. 1975.

* Address for correspondence. 
reactions with group- $F$ antiserum and cross reactions were not observed when they were tested with antisera to other groups, including group G.

Only limited metabolic studies were performed. Seven strains were inoculated on aesculinbile agar and none grew. Four of these strains grew well on aesculin-agar slopes and were capable of splitting this substrate. All strains were resistant to bacitracin.

\section{Discussion}

Bergey's Manual (Breed, Murray and Smith, 1957) uses Streptococcus anginosus as the name for streptococci belonging to group $\mathrm{F}$ and assigns priority for the description of the species to Andrewes and Horder (1906), but Wilson and Miles (1964) have suggested Streptococcus minutus as an alternative. Neither name appears yet to have received universal endorsement, although in a recent report the designation Streptococcus anginosus was used (Koepke, 1965).

Classically, these organisms are slow-growing, microaerophilic, minute haemolytic streptococci which produced such small colonies that they are often recognised only because of the surrounding haemolysis (Long and Bliss, 1934). Non-haemoytic strains have been reported, particularly from the oral cavity, where they are said to be much more common than haemolytic ones. Many of these non-haemolytic strains are said to produce larger colonies than the haemolytic variants (Ottens and Winkler, 1962). Some of the organisms studied here produced quite large haemolytic colonies and were easily visible after incubation for $24 \mathrm{~h}$ under anaerobic conditions.

Contemporary authors (Wilson and Miles, 1964; Davis et al., 1973) regard the group-F streptococcus as an inhabitant of the human throat. This concept appears to be based chiefly upon the work of Long and Bliss (1934) who isolated over 200 strains of " minute haemolytic streptococci" from throat swabs and provided some of the strains that were studied by Lancefield and Hare (1935) when they originally designated group F. These authors also reported that they isolated it more often from patients with sore throat than they did from those who were normal. They also isolated it from vaginal cultures obtained from women during the puerperium. Other sources from which it has been reported include the skin (Colebrook, Maxted and Johns, 1935) and faeces (Hare and Maxted, 1935).

None of these early workers was entirely convinced that the group-F streptococcus could be pathogenic, although the original report by Long and Bliss (1934) described three cases in which the organism was isolated from paranasal sinuses and one in which it was isolated from an abscess of the chest wall. Thomas (1939) isolated it, together with " $B$. coli", from the CSF of a patient with meningitis and more recently there have been reports of its recovery from intracranial infections (Rantz, 1942; Wheeler and Foley, 1943; Koepke, 1965). Other types of infection with which group-F streptococci have been associated include dental abscesses (Ottens and Winkler, 1962), abscess and peritonitis (Foley, 1947), infected antrum (Plummer, 1941), and chest infections (Lancefield and Hare, 1935).

Some of the present data repeat these observations. Group-F streptococci were isolated from the vagina and from the throat, although it was really quite rare in the latter situation; to isolate the four strains some 10,000 throat swabs were examined.

So far, its existence in the peritoneal cavity appears not to have been widely recognised, and yet eight of the 22 strains were recovered from this region. Most of the others came from septic lesions, but the question of pathogenicity has still not been resolved because all our strains were isolated in mixed culture and the part played by any one organism is difficult to assess.

A second conclusion is that the respiratory tract is not the only habitat of this organism (Wilson and Miles, 1964; Davis et al., 1970), and it may well be found quite often in the lower intestine and the vagina.

\section{SUMMARY}

In a 4-year study, 22 strains of group-F streptococci were isolated from children and puerperal women. All were isolated in mixed culture but were associated with sepsis or other 
pathological conditions. It appears that this organism may be an opportunistic pathogen and that its habitats include the gastrointestinal tract and the vagina as well as the throat.

I am greatly indebted to Dr A. G. Stewart for invaluable help in the preparation of the manuscript, to Miss Marlene Ward for her secretarial services and to the technical staff of the Microbiology Laboratory for their investigation of the cultures.

\section{REFERENCES}

ANDREWES, F. W. AND HoRDER, T. J. 1906. A study of the streptococci pathogenic for man. Lancet, $2,852$.

Breed, R. S., Murray, E. G. D. ANd SMrth, N. R. 1957. Bergey's Manual of determinative bacteriology, 7th ed., Baltimore, p. 516.

ColebrooK, L., MaXted, W. R. AND Johns, A. M. 1935. The presence of haemolytic and other streptococci on human skin. J. Path. Bact., 41, 521.

Davis, B. D., Dulbecco, R., Eisen, H. N., Ginsberg, H. S., WoOd, W. B. AND MCCARTY, M. 1973. Microbiology, 2nd ed., Maryland, p. 710.

FolEY, G. E. 1947. Further observations on the occurrence of streptococci of groups other than $\mathrm{A}$ in human infection. New Engl. J. Med., 237, 809.

HaRe, R. AND MAXTED, W. R. 1935. The classification of haemolytic streptococci from the stools of normal pregnant women and of cases of scarlet fever by means of precipitin and biochemical tests. J. Path. Bact., 41, 513.

KOEPKE, J. A. 1965. Meningitis due to Streptococcus anginosus (Lancefield group F). J. Am. med. Ass., 193, 739.

LANCEFIELD, R. C. 1938. A micro precipitin-technic for classifying hemolytic streptococci, and improved methods for producing antisera. Proc. Soc. exp. Biol. Med., 38, 473.

LANCEFIELD, R. C. AND HARE, R. 1935. The serological differentiation of pathogenic and non-pathogenic strains of hemolytic streptococci from parturient women. J. exp. Med., $61,355$.

Long, P. H. AND Burs, E. A. 1934. Studies upon minute hemolytic streptococci. I. The isolation and cultural characteristics of minute beta hemolytic streptococci. J. exp. Med., 60, 619.

MAXTED, W. R. 1953. The use of bacitracin for identifying group A haemolytic streptococci. J. clin. Path., 6, 224.

OTTENS, H. AND WINKLER, K. D. 1962. Indifferent and haemolytic streptococci possessing group-antigen F. J. gen. Microbiol., 28, 181.

Plummer, H. 1941. A serological and biochemical study of hemolytic streptococci. $J$. Immun., 42, 91.

RaNTZ, L. A. 1942. Streptococcal meningitis. Four cases treated with sulfonamides in which the etiological agent was an unusual streptococcus. Ann. intern. Med., 16, 716.

RaNTZ, L. A. AND RANDALl, E. 1955. Use of autoclaved extracts of hemolytic streptococci for serological grouping. Stanford med. Bull.. 13, 290.

Thomas, A. 1939. Purulent meningitis produced by the minute hemolytic streptococcus (Long and Bliss) and B. coli. J. Mt Sinai Hosp., 5. 702.

WHEELER, S. M. AND Foley, G. E. 1943. A note on non-group A streptococci associated with human infection. J. Bact., 46, 391.

Wilson, G. S. AND Miles, A. A. 1964. Principles of bacteriology and immunity, 5th ed., Baltimore, p. 719. 